\title{
Pelatihan News Reading dan Story Telling untuk English Club di SMAN Kalisat
}

\author{
Titik Ismailia, S.Pd., M.Pd ${ }^{\# 1}$, Vigo Dewangga, S.S., M.Pd. ${ }^{* 2}$, \\ ${ }^{\#}$ Jurusan Bahasa, Komunikasi, dan Pariwisata , Politeknik Negeri Jember \\ Jl. Mastrip 164 Jember \\ 1titikarulegmail.com \\ *Jurusan Bahasa, Komunikasi, dan Pariwisata, Politeknik Negeri Jember \\ Jl. Mastrip 164 Jember \\ 2filipi.beautifuldyahoo.com
}

\begin{abstract}
Kegiatan ekstrakurikuler merupakan kegiatan yang wajib diikuti oleh siswa di SMAN Kalisat. English Club (English Conversation Club) menjadi salah satu pilihan untuk dapat mempelajari Bahasa Inggris dengan lebih menyenangkan. Akan tetapi prestasi yang selama ini diperoleh belum memuaskan. Oleh karena itu penulis berinisiatif untuk memberikan pelatihan news reading dan story telling bagi anggota EEC dengan harapan akan dapat meningkatkan prestasi. Luaran yang diharapkan yaitu adanya satu divi khusus yang melatih siswa dengan teknik-teknik berkomunikasi sebagai news reader dan story teller yang unggul. Metode yang dilakukan dengan studi pendahuluan, pelatihan intensif, dan evaluasi. Dari hasil dan pembahasan diperoleh data tentang jumlah anggota 50 siswa kelas $\mathrm{X}$ dan XI, minat siswa yang sangat antusias dalam mengikuti pelatihan, dan kendala-kendala seperti belum adanya sekertariat khusus dan fasilitas yang sesuai. Walaupun demikian penulis menyarankan agar target dapat tercapai sekolah dapat menyediakan sarana yang memadai dalam melaksanakan kegiatan ekstrakurikuler ini.
\end{abstract}

Keywords - Pelatihan, News Reading dan Story Telling, E-Club SMAN Kalisat

\section{PENDAHULUAN}

SMAN Kalisat merupakan salah satu sekolah menengah di wilayah utara kabupaten Jember. Lokasi sekolah ini berbatasan dengan kecamatan Arjasa dibagian selatan, kecamatan Ledokombo di bagian utara, kecamatan Sukowono di bagian timur, dan kecamatan Mayang dibagian barat.

Di kecamatan Arjasa terdapat satau SMA yaitu SMAN Arjasa. Sedangkan SMA Kalisat yang telah ada sejak tahun 1983 dan memulai menerima siswa sejak tahun 1984. Siswa-siswanya berasal dari wilayah di sekitar kecamatan Kalisat seperti Ledokombo dan Sukowono. Di kecamatan Sukowono berdiri satu SMA yang dulunya merupakan cabang dari SMAN Kalisat yang disebut SMA Plus Sukowono. Walaupun demikian minat siswa untuk bersekolah di SMAN Kalisat tetaplah tinggi. Hal ini terbukti dengan jumlah siswa pada tahun ajaran 2015 yaitu kelas X, XI, dan XII berjumlah sekitar 600 siswa.

SMAN Kalisat telah memiliki website dengan alamat www.smankalisat.sch.id. Siswa, guru, dan masyarakat dapat mengakses informasi tentang profil sekolah, fasilitas sekolah, pendidik dan tenaga pendidik, kesiswaan, ekstra kurikuler, indexs berita, pengumuman, agenda sekolah, dan list download. Walaupun demikian terdapat beberapa konten yang belum terisi secara lengkap seperti ekstra kurikuler dan data siswa.

English Club merupakan salah satu kegiatan ekstrakurikuler yang diselenggarakan di SMA ini. Berdasarkan informasi dari salah satu guru bahwa anggotaanggotanya selalu mengikuti lomba-lomba yang diselenggarakan dalam olimpiade Bahasa Inggris seperti news reading dan story telling. Prestasi yang diperoleh diantaranya peringkat ketiga dan belum pernah menjadi juara. Oleh karena itu dibutuhkan pelatihan yang lebih intensif agar siswa dapat memiliki keterampilan berkomunikasi terutama dalam membaca berita dan bercerita.

Menurut beberapa penulis penggunaan media story telling dan news reading akan dapat meningkatkan prestasi di bidang kebahasaan seperti reading, listening, speaking, dan writing. Wahyuni (2014) mengungkapkan penggunaan media story telling untuk siswa intermediate merupakan langkah kreatif dalam pembelajaran bahasa Inggris. Hal ini akan dapat meningkatkan kemampuan siswa dalam mendengarkan cerita, menulis skrip, memahami cerita secara kronologis, dan berbicara tentang opini dalam isi 
cerita. Di samping siswa juga dapat berlatih untuk mengatur gerak tubuh, ekspresi wajah, dan memberikan pemahaman agar pendengar mengerti jalan cerita. Aktivitas dapat dilakukan dengan berkelompok maupun individu. Menurut National Story Telling Association, story telling merupakan seni menggunakan bahasa, vokalisasi, gerakan dan gestur tubuh untuk menyampaikan pesan kepada audience. Tehnik yang dapat digunakan meliputi: cerita bergambar, menulis cerita bebas berdasarkan gambar, kata-kata dalam video, diskusi, dan presentasi atau penampilan story telling. Dengan teknik ini siswa dapat meningkatkan kemampuan menulis dan berbicara.

Selanjutnya menurut Nurendah, Ananthia, dan Windayana (2014) yang melakukan penelitian tentang penggunaan metode story reading dalam pengajaran reading di SDN Cikubang Kecamatan Pamulihan Kabupaten Sumedang. Penulis mengungkapkan tentang meningkatkan kemampuan reading comprehension dengan metode story reading. Membaca merupakan kegiatan yang bertujuan untuk memahami teks sehingga guru harus menggunakan metode yang menarik agar siswa dapat memahami teks secara keseluruhan. Dengan metode story reading siswa menjadi lebih senang belajar karena terdapat cerita di dalam teks. Dengan demikian terdapat peningkatan nilai dalam evaluasi reading karena siswa menjadi lebih termotivasi dalam belajar.

Menurut Iman (2015) yang melakukan penelitian tentang penggunaan cerita pendek untuk meningkatkan kemampuan speaking dan writing mahasiswa Universitas Indo Global Mandiri. Membaca cerita dapat menjadi input untuk berlatih kemampuan bahasa yang lain seperti kemampuan berbicara. Teknik yang dapat dilakukan yaitu meminta mahasiswa bercerita menggunakan bahasa sendiri, memberikan urutan cerita secara kronologis, dan menceritakan kembali teks yang sudah dibaca. Dengan demikian pemilihan materi short stories yang menarik akan meningkatkan motivasi dan menstimulasi siswa untuk membiasakan diri aktif dalam aktivitas speaking dan reading di kelas. Selain itu juga pemilihan materi disesuaikan dengan kemampuan siswa agar target yang diinginkan dapat tercapai.

Penulis berikutnya yaitu Septanti, Ghozali, dan Robiasih (2016) berpendapat tentang penggunaan model story telling dalam pengajaran speaking memiliki beberapa kelebihan seperti pengembangan kemampuan speaking, keinginan untuk dapat menceritakan pengalaman di depan kelas, partisipasi untuk bertanya kepada presenter, keinginan untuk mengikuti kelas story telling dengan kesabaran, kekecewaan terhadap pemberian kesempatan dalam menceritakan sesuatu memiliki perbaikan. Selain itu, story telling juga merupakan aktivitas bermakna yang memberikan manfaat yaitu pengembangan kemampuan diri dan keberanian dan memberikan kesempatan dan membangun kemampuan berbicara.

\section{TARGET DAN LUARAN}

Target yanga akan dihasilkan dari program ini pengabdian masyarakat ini yaitu anggota ECC (English Conversation Club) memiliki pengetahuan berkomunikasi untuk menjadi news caster dan story teller yang baik, memiliki kemampuan publik speaking khususnya dibidang news caster dan story teller, dan memiliki kepercayaan diri untuk berbicara di depan publik. Sedangkan luaran yang dihasilkan meliputi satu divisi khusus untuk news caster dan story teller pada organisasi ECC dan peningkatan minat untuk menggunakan Bahasa Inggris sebagai sarana meningkatkan kepercayaan diri.

\section{METODE PELAKSANAAN}

Metode yang dilakukan dalam pelaksanaan pengabdian kepada masyarakat meliputi serangkain kegiatan yaitu pertama mengadakan studi pendahuluan untuk mengetahui kondisi kegiatan ECC di SMAN Kalisat. Kegiatan yang dilakukan yaitu mengetahui jumlah anggota ECC dan sarana prasarana yang dibutuhkan dalam pelatihan news reading dan story telling, dan mengadakan wawancara untuk mengetahui motivasi dan minat calon peserta pelatihan. Kedua, pelatihan intensif dengan memberikan pelatihan tentang berkomunikasi yang baik sebagai news caster dan story teller meliputi pengetahuan tentang public speaking, keterampilan berkomunikasi, dan bertindak sebagai news caster dan story teller. Ketiga, evaluasi diri dilakukan dengan mengevaluasi implementasi keseluruhan kegiatan pelatihan.

\section{IV.HASIL DAN PEMBAHASAN}

Berdasarkan hasil dan pembahasan diperoleh informasi sebagai berikut. Pada studi pendahuluan penulis bertemu dengan Ibu Retno Wahyuningsih, S.Pd selaku pembina ekstrakurikuler ECC pada minggu pertama bulan Agustus 2016. Informasi yang diperoleh meliputi sejarah berdirinya ECC sejak tahun 1998 dengan pembina Ibu Retno Wahyuningsih, S.Pd sendiri dengan jumlah anggota sekitar 20 orang yang dilatih untuk mengikuti lomba pidato (speech) di dinas pendidikan. Prestasi yang di raih cukup baik sampai menjadi juara satu tingkat kabupaten. Walaupun demikian ternyata prestasi tersebut tidak bertahan lama karena semakin lama semakin menurun. Beberapa kendala yang ditemui diantaranya kurang intensifnya waktu pelatihan dan kemampuan anggota serta motivasi yang semakin semakin menurun. Sampai dengan saat ini jumlah anggota ECC sekitar 50 orang siswa dari kelas X dan XI. Kegiatan mingguan yang dilakukan meliputi conversation practice, dan presentasi berbahasa Inggris yang dilaksanakan setiap hari sabtu sejak pukul 2 siang sampai 4 sore. Tempat kegiatan dilaksanakan di kelas yang siswanya telah pulang. Dengan demikian penulis mendapatkan informasi jika pelatihan nantinya akan dilaksanakan di ruangan kelas yang berbeda setiap minggunya.

Anggota ECC memiliki motivasi dan minat yang cukup 
besar terhadap pelatihan ini. Hal ini dikarenakan dua jenis kegiatan tersebut selalu dilombakan dalam olimpiade Bahasa Inggris. Selain itu keinginan untuk mengikuti lomba dan mendapatkan pengalaman juga masih menjadi daya tarik siswa untuk mengikuti pelatihan. Informasi teknis pelatihan didiskusikan dengan pengurus ECC dan pembina serta pembimbing. Pelatihan akan dilaksanakan dalam 12 kali pertemuan dengan uraian 7 kali untuk news caster dan untuk story teller dan satu kali evaluasi.Peserta di batasi berjumlah 20 orang untuk masing-masing kegiatan karena keterbatasan tempat dan peralatan yang dibutuhkan. Selain itu agar pelatihan ini lebih efektif dan efisien dalam melakukan pemetaan kemampuan siswa dan mengetahui kualifikasi untuk menjadi news caster dan story teller.

Kedua, pelatihan intensif yang merupakan kegiatan utama dilakukan dengan melibatkan mahasiswa yaitu Audry Reagusta Fajri yang menjuarai lomba news caster tingkat Politeknik se-Indonesia dan Agga Dwyka Robbyantama yang telah menjadi juara lomba story teller tingkat nasional. Materi dan jadwal kegiatan selengkapnya terdapat dalam tabel berikut:

TABEL I

JADWAL DAN MATERI KEGIATAN

\begin{tabular}{|l|l|l|}
\hline No. & Pertemuan ke & \multicolumn{1}{c|}{ Materi yang disajikan } \\
\hline 1. & 1 & Pengenalan umum tentang news casting \\
\hline 2. & 2 & TV News Casting \\
\hline 3. & 3 & Live Report \\
\hline 4. & 4 & Weather Forecast \\
\hline 5. & 5 & Finding Stories \\
\hline 6. & 6 & Adapting to Audiences \\
\hline 7. & 7 & Particular Oral Story Telling Skills \\
\hline 8. & 8 & Story Telling Practice \\
\hline
\end{tabular}

Ketiga, Evaluasi kegiatan yang dilakukan untuk mengetahui implemntasi kegiatan yang telah dilakukan. Selain itu untuk mengetahui manfaat pelatihan bagi anggota ECC sebagai subyek pelatihan dan sekolah sebagai tempat pelatihan. Berdasarkan hasil evaluasi terdapat beberapa permasalahan yang ditemui tim pelaksana kegiatan yang berhubungan dengan hal-hal sebagai berikut: pertama, ECC belum memiliki sekertariat khusus yang dapat digunakan untuk melakukan koordinasi dan diskusi kegiatan serta menempatkan buku-buku sumber bacaan. Hal tersebut dikarenakan adanya kebijakan sekolah gratis dimana sekolah dilarang untuk memungut biaya apapun dari siswa sehingga sekolah belum dapat menyediakan tempat khusus sebagai sekertariat ECC. Kedua, adanya pemahaman bahwa ECC bukan merupakan kegiatan yang dapat memberikan prestasi seperti olahraga dan seni yang selama ini menjadi unggulan sekolah. Ketiga, ECC belum mampu memberikan prestasi sesuai harapan sekolah. Keempat, adanya pemahaman bahwa native speaker (penutur asli) asing (bule) lebih memiliki kemampuan berbahasa Inggris dibandingkan dengan orang Indonesia yang bukan penutur asli. Kelima, belum adanya dukungan sekolah untuk dapat mengikutsertakan semua anggota dalam kegiatan lomba walaupun hanya sebagai pendukung. Keenam, belum adanya kebijakan dari sekolah agar siswa memilih sah satu kegiatan ekstrakurikuler saja sehingga ECC belum menjadi pilihan utama.

Ketujuh, belum adanya pemetaan (mapping) kemampuan anggota ECC sehingga belum dapat fokus terhadap salah satu kegiatan. Kedelapan, belum adanya motivasi dari siswa yang menjadikan ECC sebagai salah satu kegiatan ekstrakurikuler yang dapat membantu belajar Bahasa Inggris dengan lebih menyenangkan. Kesembilan, belum adanya pembina yang dapat membantu kegiatan secara terprogram agar tercapai sesuai target. Kesepuluh, belum adanya pemahaman bawa mengikuti lomba dapat memberikan pengalaman berkompetisi dan bertemu dengan peserta lain sehingga dapat saling mengenal dan bertanya tentang kegiatan dan prestasi masing-masing. Kegiatan yang diikuti pada bulan September 2016 di FKIP Universitas Jember dengan prestasi peringkat 11 dari 80 peserta di tingkat Jawa Timur.

\section{KESIMPULAN DAN SARAN}

Kesimpulan dari kegiatan pengabdian kepada masyarakat ini yaitu adanya keinginan penulis untuk dapat meningkatkan prestasi ECC ditingkat kabupaten Jember. Sealin itu juga untuk meningkatkan kualitas penguasaa Bahasa Inggris terutama dalam berkomunikasi dan presentasi. Dengan demikian guru dan siswa akan mendapatkan manfaat dari penguasaan Bahasa Inggris dengan cara yang lebih menyenangkan serta akan meningkatkan minat siswa untuk memilih ECC sebagai pilihan utama dalam kegiatan ekstrakurikuler di SMAN Kalisat.

Siswa yang menjadi anggota ECC akan memperoleh sistem pembelajaran Bahasa Inggris dengan cara yang lebih menyenangkan dan spesifik dalam berlatih percakapan dan presentasi. Sedangkan sekolah akan mendapatkan manfaat dalam prestasi siswa terutama dalam lomba news reading dan story telling yang setiap tahunnya selalu diikuti. Oleh karena itu diperlukan pelatihan secara intensif dalam memahami dan terutama mempraktekkan teknik-teknik untuk menjadi news caster dan story teller. Anggota ECC akan secara langsung mendapatkan ilmu berkomunikasi yang unggul. Siswa juga dapat langsung mempraktekkan secara langsung ilmu yang telah dipelajari dengan pengawasan sehingga jika ada kesalahan bisa segera diperbaiki.

Berdasarkan hasil pelatihan diperoleh input bahwa anggota ECC sudah mengetahui teknik-teknik berkomunikasi untuk menjadi news caster dan story teller. Para peserta juga sangat antusias mengikuti pelatihan karena ketertarikan untuk memperoleh prestasi seperti yang di dapat pemateri. Akan tetapi evaluasi menunjukkan bahwa masih terdapat beberapa kendala seperti kurangnya komitmen anggota untuk lebih serius dalam menjalani 
kegiatan ekstrakurikuler ini sebagai tempat untuk lebih berprestasi baik secara akademis maupun pribadi. Selain itu juga kurangnya fasilitas seperti tempat pelaksanaan yang selalu berpindah setiap minggunya.

\section{UCAPAN TERIMA KASIH}

Ucapan terima kasih kami sampaikan kepada pihak Politeknik Negeri Jember khususnya Pusat Penelitian dan Pengabdian kepada Masyarakat (P3M) yang telah menyelenggarakan dan mendanai program ini melalui Program Penelitian dan Pengabdian kepada Masyarakat Sumber Dana BOPTN tahun 2016.

\section{DAFTAR PUSTAKA}

[1] E. S. Wahyuni, "Improving Language Skills Through Storytelling for Intermediate Level Students," Prosiding Seminar Nasional Pendidikan Fisika dan Bahasa Inggris, Surabaya, 2014.

[2] I. Nurendah, W. Ananthia, \& H. Windayana, "Metode Story Telling untuk Meningkatkan Hasil Belajar Siswa dalam Keterampilan Reading Comprehension," Antalogi, Vol...., Nomor...., Juli, 2015.

[3] J. N. Iman, "A Quasi-Experimental Study on Using Short Stories to Improve the Speaking ang Writing Achievement of the Undergraduate Students of Urban and Regional Planning Study Program of Indo Global Mandiri University," Proceeding The 62nd TEFLIN International Conference 2015, p. 572.

[4] R. D. Septanti, I. Ghozali, \& H. Robiasih, “ Developing Students' Speaking Competence through Storytelling at the Second Grade Students of SMK 1 Magelang in Academic Year 2013/2014," dalam Bahasa, Sastra, dan Pengajarannya dalam Perspektif Ideologi, Ekologi, dan Multikulturalisme. Pusat Bahasa Universitas Tidar, Balai Bahasa Jawa Tengah, HISKI Komisariat Kedu, 2016 